\title{
Efektifitas olahraga jalan kaki terhadap kadar gula darah pada lansia dengan diabetes mellitus tipe II
}

\author{
Indirwan Hasanuddin ${ }^{1 *}$, Sigit Mulyono², Lily Herlinah ${ }^{3}$
}

\author{
1Program Studi Ilmu Keperawatan Stikes Muhammadiyah Sidrap, Sidenreng Rappang, Sulawesi Selatan. \\ *Email: Indirwan.Hasanuddin02@gmail.com \\ 2Fakultas IImu Keperawatan Universitas Indonesia. Email: Sigitmulyono29@gmail.com \\ ${ }^{3}$ Program Magister Keperawatan Fakultas Keperawatan Universitas Muhammadiyah Jakarta. \\ Email: herlinahlily@yahoo.co.id
}

\section{Abstract \\ Effects of a regular walking exercise program on blood sugar levels in elderly people with type II diabetes}

Background: Diabetes mellitus increases every year and becomes a problem that is difficult for the government to handle. In the treatment of diabetes mellitus in addition to using drugs and insulin also requires physical exercise therapy to control and reduce blood sugar levels.

Purpose: Identifying the effectiveness of walking training on blood sugar levels in elderly people with type II diabetes.

Method: The pre-experimental One-Group Pre-post Test Design. This a regular walking exercise is implemented, 3 times a week for 3 weeks, the distance traveled 1 kilometer within 30 minutes. The sample was elderly type 2 diabetes in the working area of the Pangkajene Public Health Center, Sidenreng Rappang District by a purposive sampling technique with a total of 33 respondents. Data analysis was performed using a dependent t-test.

Results: Finding a decrease in average blood sugar levels by a regular walking exercise program.

Conclusion: Statistical test results obtained $p$ value $=0,000(p<0.05)$ which means it can reduce blood sugar levels. It is recommended that a regular walking exercise program can be implemented to the resolution of nursing care to patients with diabetes to reduce and control blood sugar levels.

\section{Keywords: A regular walking exercise program; Blood sugar levels; Elderly people; Type II diabetes}

Pendahuluan: Diabetes mellitus meningkat setiap tahun dan menjadi masalah yang sulit ditangani oleh pemerintah. Dalam pengobatan diabetes mellitus selain menggunakan obat-obatan dan insulin juga memerlukan terapi olahraga fisik untuk mengendalikan dan mengurangi kadar gula darah.

Tujuan: Mengidentifikasi efektivitas olahraga jalan kaki tehadap kadar gula darah pada lansia dengan diabetes tipe II.

Metode: Desain Uji Pra-Pasca Satu Kelompok pra-eksperimental. Olahraga berjalan teratur ini dilaksanakan, 3 kali seminggu selama 3 minggu, jarak yang ditempuh 1 kilometer dalam 30 menit. Sampel adalah lansia diabetes tipe 2 di wilayah kerja Puskesmas Pangkajene, Kabupaten Sidenreng Rappang dengan teknik purposive sampling dengan total 33 responden. Analisis data dilakukan dengan menggunakan uji-t dependen.

Hasil: Didapatkan penurunan kadar gula darah rata-rata dengan program olahraga berjalan teratur.

Simpulan: Hasil uji statistik diperoleh nilai $p=0,000(p<0,05)$ yang artinya dapat menurunkan kadar gula darah. Dianjurkan agar program olahraga berjalan yang teratur dapat diterapkan pada resolusi asuhan keperawatan untuk pasien diabetes untuk mengurangi dan mengendalikan kadar gula darah.

Kata kunci: Diabetes mellitus tipe II; Lansia; Olahraga jalan kaki; Kadar gula darah. 
Efektifitas olahraga jalan kaki terhadap kadar gula darah pada lansia dengan diabetes melitus tipe II

\section{PENDAHULUAN}

Keberhasilan pembangunan adalah cita-cita suatu bangsa yang terlihat dari peningkatan taraf hidup dan Umur Harapan Hidup (UHH). Dampak peningkatan UHH ini dapat meningkatkan jumlah lanjut usia (lansia) dengan angka kesakitan karena penyakit degeneratif (Kementerian Kesehatan Republik Indonesia, 2013). Sementara untuk angka harapan hidup bagi lansia paling tinggi pada perempuan dibandingkan dari pada laki-laki, hal ini terlihat dengan keberadaan penduduk lansia perempuan yang lebih banyak dari pada lansia laki-laki, dimana jumlah lansia di Indonesia yang berjenis kelamin perempuan sebesar 9,53\% sedangkan laki-laki sebesar 8,54\% (Kementerian Kesehatan Republik Indonesia, 2017).

Peningkatan jumlah lansia ini dapat mengakibatkan tingginya masalah pada kesehatan salah satunya pada masalah penyakit tidak menular (PTM) yaitu diabetes mellitus karena pada proses ini tepatnya pada proses pertambahan usia dapat beresiko terserang penyakit DM atau disebut juga dengan prediabetes, suatu keadaan dimana kondisi gula darah puasa pada seseorang berada diangka 100-120 mg/DI atau gangguan toleransi gula dalam darah (140-199 mg/dL), sehingga apabila kadar gula darah seseorang tersebut mencapai angka $\geq 200 \mathrm{mg} / \mathrm{Dl}$ maka sesorang tersebut digolongkan diabetes mellitus (DM). Pada lanjut usia resistensi insulin akibat gangguan metabolisme karbohidrat disebabkan karena beberapa faktor, seperti berkurangnya reseptor insulin yang disebabkan karena kurangnya beraktivitas fisik, terjadinya penimbunan lemak dalam tubuh, pola makan lansia yang lebih sering karena mengkonsumsi karbohidrat akibat jumlah gigi yang mulai berkurang serta perubahan neurohormonal IGF-1 (insulin-like growth factor-1) dan DHEAS (dehidroepiandesteron) yang menyebabkan penurunan ambilan glukosa. Selain itu ganguan yang terjadi pada metabolisme lipid dapat meningkatkan berat badan hingga obesitas dan hipertensi (Kurniawan, 2010).

Data yang didapat dari International Diabetes Federation, pada tahun 2013 jumlah penderita DM sebanyak 381 juta jiwa, pada tahun 2015 mengalami peningkatan menjadi 415 juta jiwa dan pada tahun 2017 bertambah menjadi 425 juta jiwa dan diperkirakan akan mengalami peningkatan sebanyak 48\% pada tahun 2045 yakni sebanyak
629 juta jiwa. Indonesia saat ini menduduki peringkat ke 6 (enam) di dunia dari 10 negara terbanyak penyandang DM sebanyak 10 juta jiwa (International Diabetes Federation, 2017). Presentasi gula darah tinggi menurut umur sebagain besar pada kelompok umur _60 tahun sebesar 38.3\% (Kementerian Kesehatan Republik Indonesia, 2018) menunjukkan prevalensi Penyakit Tidak Menular mengalami kenaikan diantaranya penyakit diabetes mellitus itu sendiri yang mengalami peningkatan prevalensi berdasarkan pemeriksaan gula darah, diabetes melitus naik dari tahun $2013(6,9 \%)$ hingga tahun 2018 menjadi $(8,5 \%)$. Presentasi terbesar penyandang DM di Provinsi DKI $(3,4 \%)$ dan presentasi yang terkecil di Propinsi NTT $(0,9 \%)$, sedangkan untuk wilayah provinsi sulawesi selatan mencapai $(1,8 \%)$.

Adapun dana yang dikeluarkan oleh BPJS untuk pengobatan diabetes pada tahun 2018 sebanyak Rp. 6,1 triliun, diabetes mellitus merupakan penyakit kronis yang memiliki biaya tertinggi sebanyak Rp. 6,1 triliun, sekitar 87,5\% digunakan untuk menangani pasien diabetes yang sudah kompilkasi, hanya sekitar $0,5 \%$ yang digunkan untuk membeli obat. Hal ini menandakan masih tingginya dana yang dikeluarkan oleh pemerintah untuk penanganan penyakit diabetes mellitus di Indonesia (Maharani, 2019; Perkumpulan Endokrinologi Indonesia, 2015).

Penalataksanaan penderita DM dapat dilakukan dengan kegiatan jasmani sehari-hari dan olahraga jasmani secara teratur yaitu 3-5 hari seminggu selama sekitar 30-45 menit, dengan total 150 menit perminggu, dengan jeda antar olahraga tidak lebih dari 2 hari berturut-turut. Olahraga jasmani yang dianjurkan berupa olahraga jasmani yang bersifat aerobik salah satunya jalan kaki (Perkumpulan Endokrinologi Indonesia, 2015). Aktivitas fisik seseorang bermanfaat untuk kesehatan semua umur, termasuk lansia itu sendiri. Walaupun terdapat bermacam-macam jenis olahraga, berjalan dan gerak rentang sendi merupakan bentuk latihatan yang paling baik, dan olahraga ini bebas di lakukan dimana dan kapan pun. Dimana fungsi olahraga jalan kaki ini adalah salah satunya menurunkan resistensi insulin (Mauk, 2014).

Olahraga jalan kaki dapat meningkatkan insulin mengikat reseptor pada membran sel otot. Dimana insulin sebenarnya merupakan suatu modulator

Indirwan Hasanuddin' Program Studi llmu Keperawatan Stikes Muhammadiyah Sidrap, Sidenreng Rappang, Sulawesi Selatan. *Email: Indirwan.Hasanuddin02@gmail.com

Sigit Mulyono² Fakultas 1lmu Keperawatan Universitas Indonesia. Email: Sigitmulyono29@gmail.com

Lily Herlinah ${ }^{3}$ Program Magister Keperawatan Fakultas Keperawatan Universitas Muhammadiyah Jakarta.

Email: herlinahlily@yahoo.co.id 
Efektifitas olahraga jalan kaki terhadap kadar gula darah pada lansia dengan diabetes melitus tipe II

transportasi glukosa selama olahraga dan olahraga yang memperbesar efeknya. Pada saat terjadi perubahan konsentrasi insulin dan glucogan inilah yang mencegah penurunan kadar glukosa darah selama olahraga, awalnya dengan merangsang glikogenolisis hati dan kemudian oleh peningkatan glukoneogenesis hepatik. Adapun beberapa faktorfaktor yang terlibat dalam mekanisme penyerapan glukosa meningkat selama dan setelah olahraga sehingga meningkatkan laju aliran darah ke otot yaitu berolahraga, perubahan status energi dari otot dan peningkatan insulin mengikat serta mekanisme sinyal seluler yang juga berperan dalam merangsang transporter glukosa (Sirisha, \& Paramjyothi, 2015).

\section{METODE PENELITIAN}

Desain penelitian kuantitatif, menggunakan metode pra experiment dengan pre- dan post-test one group design. Dimana pada rancangan ini tidak ada kelompok pembanding (kontrol) dengan sampel ditentukan dengan teknik purposive sampling sebanyak 33 lansia. Olahraga jalan kaki ini dilaksanakan selama 3 kali seminggu selama 3 minggu perlakuan tanpa melebihi jeda 2 hari olahraga, jarak yang ditempuh 1 kilometer dengan waktu 30 menit dengan pemeriksaan kadar gula darah pretest dan posttest, dan dilakukan secara berkelompok di sebuah lapangan serta dilaksanakan pada pagi hari dengan terlebih dahulu responden sarapan pagi dengan 1 buah apel setara dengan 72 kalori. Nilai IMT responden rata-rata 24 - 26 dengan kategori gemuk dengan resiko dan obesitas tingkat $\mathrm{I}$.

Selama penelitan ini berlansung faktor yang tidak bisa dikendalikan adalah responden secara bersamaan mengonsumsi obat hipoglikemik oral $(\mathrm{OHO})$ dari dokter. Penelitian ini telah lolos kaji etik dengan nomor surat 0240/F.9-UMJ/II/2019. Penelitian ini dilaksanakan dimulai dari persiapan penelitian dan proposal diajukan pada bulan Februari-April 2019, dan pengumpulan data akan dilakukan selama empat minggu, yaitu pada bulan April 2019.

Dalam penelitian ini proses pengambilan dan pengumpulan data diperoleh dengan lembar observasi pengukuran kadar glukosa darah. Alat yang digunakan dalam pengukuran kadar glukosa darah adalah blood glucose test. Variable dalam penelitian ini adalah variabel independen (bebas) yaitu olahraga jalan kaki,variable dependennya (terikat) adalah kadar gula darah.

\section{HASIL}

Tabel 1. Distribusi Responden Berdasarkan Usia Lansia Diabetes Mellitus Tipe II N=33

\begin{tabular}{ccc}
\hline Variabel & Frekuensi (f) & Persentase (\%) \\
\hline Usia & & \\
60-61 Tahun & 26 & 78,8 \\
62-63 Tahun & 7 & 21,2 \\
Jenis kelamin & & \\
Laki -laki & 12 & 36,4 \\
Perempuan & 21 & 63,6 \\
IMT & & \\
Normal & 14 & 42,4 \\
Tidak Normal & 19 & 67,6
\end{tabular}

Sumber: Data PrimerTahun 2019

Indirwan Hasanuddin' Program Studi llmu Keperawatan Stikes Muhammadiyah Sidrap, Sidenreng Rappang, Sulawesi Selatan. *Email: Indirwan.Hasanuddin02@gmail.com

Sigit Mulyono ${ }^{2}$ Fakultas Ilmu Keperawatan Universitas Indonesia. Email: Sigitmulyono29@gmail.com

Lily Herlinah ${ }^{3}$ Program Magister Keperawatan Fakultas Keperawatan Universitas Muhammadiyah jakarta.

Email: herlinahlily@yahoo.co.id 
Efektifitas olahraga jalan kaki terhadap kadar gula darah pada lansia dengan diabetes melitus tipe II

Berdasarkan pada tabel diatas dapat dilihat bahwa dari semua responden Lansia Diabetes Mellitus Tipe II didapatkan usia termuda 60 tahun dan tertua 63 tahun. dari 33 responden, responden yang berjenis kelamin perempuan lebih banyak dari pada lakik-laki, dimana jumlah responden perempuan sebanyak 21 (63,6 \%) responden. dari 33 responden, reponden yang memiliki indek massa tubuh tidak normal lebih banyak dari pada reponden yang memiliki indek massa tubuh normal, dimana jumlah responden yang memiliki indek massa tubuh tidak normal dengan nilai IMT responden pada penelitian ini rata-rata $24-26$ dengan kategori gemuk dengan resiko dan obesitas tingkat 1 sebanyak $19(57,6 \%)$.

Tabel 2. Distribusi Rerata Gula Darah Sebelum Dan Setelah Diberikan Olahraga Jalan Kaki

\begin{tabular}{lccccc}
\hline \multicolumn{1}{c}{ Variabel } & $\mathbf{n}$ & Mean & SD & Min & Max \\
\hline Minggu I & & & & & \\
$\quad$ Rerata Pre I & 33 & 256,3 & 61,4 & 121 & 400 \\
$\quad$ Rerata Post I & & 223,1 & 48,9 & 124 & 365 \\
$\begin{array}{l}\text { Minggu II } \\
\quad \text { Rerata Pre II }\end{array}$ & 33 & 221,8 & 53,9 & 115 & 365 \\
$\quad$ Rerata Post II & & 181,3 & 54,7 & 102 & 324 \\
Minggu III & & & & & \\
$\quad$ Rerata Pre III & 33 & 201,8 & 48,0 & 146 & 317 \\
$\quad$ Rerata Post III & 33 & 151,6 & 46,6 & 102 & 248 \\
\hline
\end{tabular}

Sumber : Data Primer Tahun 2019

Berdasarkan pada tabel diatas dapat dilihat bahwa dari semua responden lansia penderita diabetes mellitus tipe II di wilayah kerja puskesmas pangkajene kabupaten sidenreng Rappang mempunyai rata-rata (mean) gula darah setelah pemberian olahraga jalan kaki pada minggu pertama rerata gula darah sebesar 223,1 mg/dl, pada minggu kedua rerata gula darah sebesar $181,3 \mathrm{mg} / \mathrm{dl}$, sedangkang pada pada minggu ketiga rerata gula darah sebesar 151,6 mg/dl. Dan untuk rata-rata (mean) gula darah setelah pemberian olahraga jalan kaki pada minggu pertama rerata gula darah sebesar 223,1 mg/dl, pada minggu kedua rerata gula darah sebesar 181,3 mg/dl, sedangkang pada pada minggu ketiga rerata gula darah sebesar $151,6 \mathrm{mg} / \mathrm{dl}$.

Tabel 3. Hasil Perubahan Gula Darah Sebelum Dan Setelah Diberikan Olahraga Jalan Kaki

\begin{tabular}{lllllll}
\hline Variabel & Tahap & $\mathbf{n}$ & Mean & Selisih & SD & p-Value \\
& & & & & & \\
\hline Gula darah & Sebelum & \multirow{2}{*}{33} & 226,67 & 41,27 & 49,16 & \multirow{2}{*}{0,000} \\
& Setelah & & 185,40 & & 43,99 & \\
\hline
\end{tabular}

Sumber: Data Primer Tahun 2019

Berdasarkan pada tabel diatas dapat dilihat bahwa perbedaan gula darah sebelum olahraga jalan kaki dalam rata-rata (mean) yaitu 226,67 mgdl, sedangkan setelah olahraga jalan kaki dalam rata-rata (mean) yaitu 185,40 mgdl dengan nilai $p$ $=0,000(p<a)$ dimana dapat disimpulkan ada perbedaan yang signifikan rata-rata gula darah yang dilihat dari nilai gula darah sebelum dan setelah diberikan olahraga jalan kaki.

Indirwan Hasanuddin' Program Studi llmu Keperawatan Stikes Muhammadiyah Sidrap, Sidenreng Rappang, Sulawesi Selatan. *Email: Indirwan.Hasanuddin02@gmail.com

Sigit Mulyono² Fakultas Ilmu Keperawatan Universitas Indonesia. Email: Sigitmulyono29@gmail.com

Lily Herlinah ${ }^{3}$ Program Magister Keperawatan Fakultas Keperawatan Universitas Muhammadiyah Jakarta.

Email: herlinahlily@yahoo.co.id 
Efektifitas olahraga jalan kaki terhadap kadar gula darah pada lansia dengan diabetes melitus tipe II

\section{PEMBAHASAN}

Bahwa dari hasil penelitian ini rata-rata penyakit diabetes mellitus diderita oleh lansia usia pertengahan yang berusia $60-63$ tahun. Kondisi ini sesuai dengan data (Kementerian Kesehatan Republik Indonesia, 2018), menunjukkan bahwa prevalensi Penyakit Tidak Menular mengalami kenaikan diantaranya penyakit diabetes mellitus itu sendiri yang mengalami peningkatan prevalensi berdasarkan pemeriksaan gula darah, diabetes melitus naik dari tahun $2013(6,9 \%)$ hingga tahun 2018 menjadi $(8,5 \%)$ dan untuk usia pravelensi tertinggi didapatkan pada usia 55-64 tahun $(6,3$ $\%$ ),menurut konsep yang ada umur adalah salah satu faktor risiko yang tidak diubah, penyakit Diabates mellitus tipe 2 sering kali ditemukan pada lansia yang berusia $\geq 60$ tahun, sekitar $85-90 \%$ jumlah penderitanya. Dengan insidens tertinggi juga didapatkan pada kelompok usia tersebut (Ubink-Veltmaat, et al, 2003). Usia yang semakin tua kecenderungan organ-organ dalam tubuhnya mulai melemah, begitu pula dengan kepekaanya terhadap insulin bahkan perempuan yang sudah menopause cenderung tidak peka lagi terhadap hormone insulin sehingga dia lebih terserang penyakit diabetes mellitus tersebut (Fitriana, \& Rachmawati, 2016).

Bahwa dari hasil penelitian ini rata-rata penyakit diabetes mellitus diderita oleh lansia yang berjenis kelamin perempuan sebanyak 21 (63,6 $\%$ ). Berdasarkan data prevelensi diabetes mellitus lebih banyak diderita oleh wanita $(12,7 \%)$ sedangkan laki-laki $(9,0 \%)$, hasil tersebut sesuai dengan temuan dan teori yang menyatakan bahwa penderita diabetes mellitus lebih banyak di derita oleh wanita dibandingkan dengan laki-laki hal ini dikarenakan lebih banyaknya timbunan lemak pada badan wanita dibandingkan dengan laki-laki, yang merupakan salah satu faktor yang dapat menurunkan sensitifitas kerja insulin pada otot hati (Smeltzer, 2008; Kementerian Kesehatan Republik Indonesia, 2018). Sedikitnya jumalh paralelaki yang memiliki berat badan lebih dibandingkan dengan perempuan, hal ini LDL tingkat trigliserida pada perempuan lebih tinggi dari pada laki-laki. Jumlah lemak pada laki-laki lebih sedikit dibandingkan dengan perempuan hal ini tercatat bahwa jumlah lemak pada laki-laki dewasa berkisar rata-rata antara $15-20 \%$ dari berat badan totalnya dan untuk perempuan sediri sekitar 20$25 \%$, sehingga perempuan 3-7 kali lebih beresiko dibandingkan dengan laki-laki 2-3 kali terkena penyakit diabetes mellitus (Jelantik, \& Haryati, 2014). Hal tersebut juga sesuai dengan hasil penelitian sebelumnya didapatkan sebanyak 18 orang dengan persentasen $62,1 \%$ yang memiliki kadar gula darah tidak terkendali adalah perempuan (Trisnawati, \& Setyorogo, 2013).

Bahwa dari hasil penelitian ini rata-rata penyakit diabetes mellitus diderita oleh responden lansia yang memiliki indeks massa tubuh tidak normal dengan nilai IMT > 22,9 sebanyak $19(57,6$ $\%)$ responden. Hal ini menunjukkan bahwa responden DM tipe II rata - rata memiliki berat badan yang tidak normal. Hal ini sesuai dengan konsep teori yang menjelaskan bahwa salah satu penyebab penyakit diabetes mellitus adalah obesitas. Obesitas merupakan salah satu faktor resiko, kenaikan berat badan juga dapat membuat kerusakan kemapuan sel $\beta$ untuk melepas insulin pada saat terjadi peningktan glukosa dalam darah (Smeltzer \& Bare, 2013).

Sebagaimana dengan hasil penelitian sebelumnya yang menunjukan bahwa ada hubungan antara indeks massa tubuh seseorang dengan kadar gula darah, apabila nila indeks massa tubuh seseorang makin tinggi makan makin tinggi pula nilai kadar gula darahnya (Adnan, Mulyati, \& Isworo, 2013).

\section{Rerata gula darah sebelum dan setelah olahraga jalan kaki.}

Berdasarkan hasil penelitian bahwa masih ada beberapa responden yang memiliki nilai kadar gula darah diatas normal. Jika dilihat lebih mendalam hal ini disebabkan oleh beberapa faktor yang mempengaruhi kadar gula darah yaitu berat badan dan usia. Oleh karena itu peneliti berpendapat bahwa menjaga berat badan melalui aktifitas fisik sangat penting, hal ini terbukti menurunkan kadar gula darah. Dengan menjaga berat badan ideal dapat menurunkan peningkatan intoleransi

Indirwan Hasanuddin' Program Studi llmu Keperawatan Stikes Muhammadiyah Sidrap, Sidenreng Rappang, Sulawesi Selatan. *Email: Indirwan.Hasanuddin02@gmail.com

Sigit Mulyono² Fakultas 1lmu Keperawatan Universitas Indonesia. Email: Sigitmulyono29@gmail.com

Lily Herlinah ${ }^{3}$ Program Magister Keperawatan Fakultas Keperawatan Universitas Muhammadiyah Jakarta.

Email: herlinahlily@yahoo.co.id 
Efektifitas olahraga jalan kaki terhadap kadar gula darah pada lansia dengan diabetes melitus tipe II

glukosa. Dalam penelitian ini terbukti terdapat kesesuaian antara teori dengan fakta bahwa berat badan menjadi salah satu faktor resiko lingkungan yang sangat penting untuk terjadinya diabetes melitus tipe II. Dalam hal ini obesitas akan meningkatkan resistensi insulin oleh tubuh sehingga glukosa didalam darah tidak mampu dimetabolisme dengan baik oleh sel dan akhirnya terjadi peningkatan glukosa dalam darah dan dengan peningkatan usia dapat memicu terjadinya peningkatan intoleransi glukosa (Waspadji, 2009). Sesuai teori yang menyebutkan bahwa orang dengan obesitas memiliki risiko penyakit Diabetes Mellitus lebih besar dibandingkan penyakit lain. Prevalensi Diabetes Mellitus Tipe II sejalan dengan peningkatan prevalensi obesitas, sekitar $80 \%$ orang dengan Diabetes Mellitus Tipe II adalah obesitas (Sari, 2019)

\section{Perubahan gula darah sebelum dan setelah olahraga jalan kaki.}

Dalam penelitian ini intervensi yang diberikan berupa pemberian olahraga jalan kaki dan dilakukan pengukuran pre test dan post test. Penurunan glukosa darah secara akut terhadap penderita diabetes melitus tipe 2 terjadi karena pada saat olahraga jalan kaki secara klinis dapat menyebabkan peningkatan kontraksi otot utamanya otot ekstremitas bawah. Hal ini terjadi akibat, insulin dan olahraga bekerja sama meningkatkan ambilan glukosa otot melalui translokasi glucose transporter 4. Insulin memberikan sinyal yang menyebabkan fosforilasi terhadap insulin receptor, insulin receptor substrate-1/2 dalam tyrosine residues dan aktivasi phosphatidylinositol 3-kinase (Stanford \& Goodyear, 2014). Salah satu perawatan non farmakologis yang baik bagi penderita diabetes mellitus tipe II yang dapat memberikan efisiensi terhadap control gula darah adalah menjalankan dengan menjalankan salah satu program olahraga fisik aerobic yakni jalan kaki (Asano, Sales, Browne, Moraes, Junior, \& Simoes, 2014). Beberapa manfaat olahraga fisik secara teratur diantaranya olahraga fisik bagi penderita diabetes mellitus yaitu selama dan sesudah olahraga fisik dapat meningkatkan uptake glukosa oleh jaringan, dapat meningkatkan enzim anti oksidan, menurunkan tekanan darah serta resistensi pada pembuluh darah, meningkatkan translokasi transport glukosa serta memperbaiki sensitivitas insulin (Arsa, de Jesus Lima, Motta-Santos, Cambri, Campbell, Lewis, \& Simões, 2015).

Penelitian sebelumnya menyatakan bahwa dengan jalan kaki ringan selama 30 menit dapat menurunkan kadar gula darah pada lansia penderita diabetes mellitus tipe II yang ditunjukkan dengan hasil yang di dapatkan nilai $p=0,000$ dan $a$ $=0,05$ yang berarti nilai $(p \leq 0,05)$, sehingga dapat disimpulkan bahwa ada pengaruh jalan kaki ringan selama 30 menit sangat baik dan penting untuk penderita diabetes melitus tipe II karena terbukti dapat menurunkan kadar gula darah pada lansia penderita diabetes mellitus (Yitno, \& Riawan, 2017).

Hasil penelitian juga sejalan dengan penelitian yang telah dilakukan di Andhra Pradesh India yang menujukan adanya perubahan signifikan dalam Gula Darah setelah berjalan selama 30 menit dengan $p$-value $<0,001$ (Sirisha, \& Paramjyothi, 2015). Hasil penelitian ini diperkuat dengan penelitian sebelumnya yang mengatakan bahwa dengan melakukan secara rutin jalan kaki selama 3-4 kali seminggu sangat bermanfaat untuk mempercepat peningkatan glukosa transporter tipe 4 (GLUT4), transporter gula darah dalam otot rangka, sehingga penyerapan glukosa serta oksidasi asam lemak akan di percepat, penelitian ini dilakukan pada satu kelompok saja tanpa ada kelompok pembanding dengan jumlah sampel sebanyak 37 penderita diabetes mellitus tipe II dengan hasil uji statistik didapatkan nilai mean kadar glukosa darah sebelum intervensi (pre test) yaitu $258,54 \mathrm{mg} / \mathrm{dl}$ sedangkan nilai mean pada hasil setelah intervensi (post test) yaitu 202,19 $\mathrm{mg} / \mathrm{dl}$, dari data hasil penelitian tersebut dapat dilihat terdapat penurunan nilai mean kadar glokosa darah sebesar 56,35 mg.dl. Untuk hasil uji dependent $t$ test kadar glukosa darah sebelum intervensi (pre test) dan setelah intervensi (post test) didapatnkan nilai $p=0,001$ atau nilai $p<0,05$, berdasarkan hasil penelitian tersebut dapat

Indirwan Hasanuddin' Program Studi llmu Keperawatan Stikes Muhammadiyah Sidrap, Sidenreng Rappang, Sulawesi Selatan. *Email: Indirwan.Hasanuddin02@gmail.com

Sigit Mulyono ${ }^{2}$ Fakultas 1lmu Keperawatan Universitas Indonesia. Email: Sigitmulyono29@gmail.com

Lily Herlinah ${ }^{3}$ Program Magister Keperawatan Fakultas Keperawatan Universitas Muhammadiyah Jakarta.

Email: herlinahlily@yahoo.co.id 
Efektifitas olahraga jalan kaki terhadap kadar gula darah pada lansia dengan diabetes melitus tipe II

disimpulkan bahwa ada pengaruh jalan kaki terpogram terhadap perubahan kadar glukosa darah pada penderita diabetes mellitus tipe II (Yusra, 2016).

\section{SIMPULAN}

Sebagian besar responden berada pada usia lansia usia pertengahan, berjenis kelamin perempuan dan memiliki indeks massa tubuh yang tidak normal. Terjadi perubahan skor rata-rata kadar gula darah sebelum dan sesudah diberi intervensi jalan kaki selama 30 menit yang dilakukan 3 kali seminggu.

\section{SARAN}

Hasil penelitian ini bisa dijadikan pertimbangan menjadi intervensi alternative pada saat melakukan penyuluhan masyarakat yang dapat dilakukan oleh perawat. Perlu menyusun program kegiatan untuk memberikan sosialisasi dan edukasi atau penyuluhan yang dapat membantu meningkatkan pengetahuan pasien DM tipe II agar mampu melakukan olahraga jalan kaki yang baik dan benar untuk menurunkan kadar gula darah pada pasien DM tipe II.

Hasil penelitian ini dapat dijadikan data dasar untuk penelitian berikutnya khususnya mengenai intervensi terkait dengan olahraga fisik khusunya pada responden lansia pada pasien DM tipe II dan penelitian selanjutnya tidak hanya menggunakan metode kuantitatif tetapi juga kualitatif untuk mendapatkan informasi yang mendalam dengan mix methods. Selain itu diharapkan penelitian selanjutnya menggunakan sampel yang lebih besar dan dapat menganalisis lebih mendalam mengenai faktor-faktor confounding yang dapat mempengaruhi penyebab terjadinya penurunan atau kenaikan kadar gula darah, seperti pola makan, ras, riwayat pengobatan, dan lama menderita dll.

\section{DAFTAR PUSTAKA}

Adnan, M., Mulyati, T., \& Isworo, J. T. (2013). Hubungan Indeks Massa Tubuh (IMT) dengan kadar gula darah penderita diabetes mellitus (DM) tipe 2 rawat jalan di RS Tugurejo Semarang. Jurnal Gizi, 2(1).

Arsa, G., de Jesus Lima, L. C., Motta-Santos, D., Cambri, L. T., Campbell, C. S. G., Lewis, J. E., \& Simões, H. G. (2015). Effects of prior exercise on glycemic responses following carbohydrate inges on in individuals with type 2 diabetes. Journal of clinical and translational research, 1(1), 22.

Asano, R.Y ., Sales, M.M., Browne, R.A.V., Moraes, J.F.V.N., Junior, H.J.C., \& Simoes, H.G. (2014). Acute effects of physical exercise in type 2 diabetes : a review.World Journal of Diabetes, 5(5) 659 - 665, doi: 10.4239/ wjd. V5.i5. 659.

Fitriana, R., \& Rachmawati, S. (2016). Cara Ampuh Tumpas Diabetes. Yogyakarta: Medika.

International Diabetes Federation. (2017). IDF Diabetes Atlas. Edisi 8 Tahun 2017. Diakses dari: https://www.idf.org/e-library/epidemiologyresearch/diabetes-atlas/134-idf-diabetes-atlas8th-edition.html

Jelantik, I. G. M. G., \& Haryati, E. (2014). Hubungan faktor risiko umur, jenis kelamin, kegemukan dan hipertensi dengan kejadian diabetes mellitus tipe II di wilayah kerja Puskesmas Mataram. Media Bina IImiah, 8(1), 39-44.

Kementerian Kesehatan Republik Indonesia. (2013). Diabetes melitus penyebab kematian nomor 6 di dunia. Diakses dari: https://www.kemkes.go.id/article/view/2383/diabet es-melitus-penyebab-kematian-nomor-6-di-duniakemenkes-tawarkan-solusi-cerdik-melaluiposbindu.html 
Efektifitas olahraga jalan kaki terhadap kadar gula darah pada lansia dengan diabetes melitus tipe II

Kementerian Kesehatan Republik Indonesia. (2013). Diabetes melitus penyebab kematian nomor $6 \mathrm{di}$ dunia. Diakses dari: https://www.kemkes.go.id/article/view/2383/diabet es-melitus-penyebab-kematian-nomor-6-di-duniakemenkes-tawarkan-solusi-cerdik-melaluiposbindu.html

Kementerian Kesehatan Republik Indonesia. (2017). Analisis lansia di Indonesia. Pusat data dan informasi, hh, 1-2. Diakses dari: https://pusdatin.kemkes.go.id/article/view/180126 00001/analisis-lansia-di-indonesia-2017.html

Kementerian Kesehatan Republik Indonesia. (2018). Riskesdas: angka kejadian 10 penyakit di indonesia . French. Retrieved from http://www.who.int/about/licensing/\%5Cnhttp://ap ps.who.int/iris/bitstream/10665/204871/1/9789241 565257_eng.pdf

Kurniawan, I. (2010). Diabetes melitus tipe 2 pada usia lanjut. Majalah Kedokteran Indonesia, 60(12), 576-584.

Maharani. A, (2019). BPJS Kesehatan keluar Rp6,1 triliun untuk tangani diabetes. Beritagar merawat Indonesia. https://beritagar.id/artikel/berita/bpjskeluar-rp61-triliun-untuk-tangani-diabetes tanggal 1 agustus 2019

Mauk, K. L. (2014). Gerontological nursing: Competencies for care. Jones \& Bartlett Publishers.

Perkumpulan Endokrinologi Indonesia (2015), Penatalaksanaan Dm Sesuai Konsesnsus Perkeni 2015 Https:/Www.Academia.Edu/34970845/Penatalak sanaan_Dm_Sesuai_Konsesnsus_Perkeni_2015 Diakses Pada tanggal 15 Desember 2018.

Sari, N. N. (2019). Hubungan obesitas sentral dengan kejadian diabetes mellitus tipe II. Jurnal IImiah Keperawatan Sai Betik, 14(2), 157-161.
Sirisha, R., \& Paramjyothl, P. (2015). Effect of Walking on Fasting Blood Sugar in Type 2 Diabetes. Bulletin of Pharmaceutical and Medical Sciences (BOPAMS), 3(1).

Smeltzer, S. C. (2008). Buku Ajar Keperawatan Medikal Bedah Brunner \& Suddarth Vol 2 Edisi 8, EGC.

Smeltzer, S. C., \& Bare, B. G. (2013). Buku ajar keperawatan medikal bedah Brunner \& Suddarth. (A. Waluyo, Ed) (8th ed). Jakarta : EGC.

Stanford, K. I., \& Goodyear, L. J. (2014). Exercise and type 2 diabetes: molecular mechanisms regulating glucose uptake in skeletal muscle. Advances in Physiology Education. 38. Oktober 2014: $308-314$.

Trisnawati, S. K., \& Setyorogo, S. (2013). Faktor risiko Kejadian diabetes melitus tipe II di puskesmas kecamatan cengkareng Jakarta Barat Tahun 2012. Jurnal IImiah Kesehatan, 5(1), 6-11.

Ubink-Veltmaat, L. J., Bilo, H. J. G., Groenier, K. H., Houweling, S. T., Rischen, R. O., \& Meyboom-de Jong, B. (2003). Prevalence, incidence and mortality of type 2 diabetes mellitus revisited: a prospective population-based study in The Netherlands (ZODIAC-1). European journal of epidemiology, 18(8), 793-800

Waspadji, S. (2009). Diabetes Mellitus:Mekanisme Dasar Dan Pengelolahannya Yang Rasional Dalam Soegondo, S ., Soewondo , P., Subekti, I., Penatalaksanaan diabetes mellitus terpadu. Jakarta : FKUI

Yitno, Y., \& Riawan, A. W. (2017). Pengaruh Jalan Kaki Ringan 30 Menit terhadap Penurunan Kadar Gula Darah pada Lansia Penderita Diabetes Melitus Tipe 2. STRADA Jurnal IImiah Kesehatan, 6(2), 8-15

Yusra, A. (2016). Pengaruh Walking Exercise Terprogram Terhadap Perubahan Kadar Glukosa Darah pada Penderita Diabetes Mellitus Tipe 2 di Wilayah Kerja Puskesmas Samudera Kabupaten Aceh Utara (Master's thesis).

Indirwan Hasanuddin' Program Studi llmu Keperawatan Stikes Muhammadiyah Sidrap, Sidenreng Rappang, Sulawesi Selatan. *Email: Indirwan.Hasanuddin02@gmail.com

Sigit Mulyono² Fakultas 1lmu Keperawatan Universitas Indonesia. Email: Sigitmulyono29@gmail.com Lily Herlinah ${ }^{3}$ Program Magister Keperawatan Fakultas Keperawatan Universitas Muhammadiyah jakarta. Email: herlinahlily@yahoo.co.id 